\title{
The origin and early application of the principle of sustainable forest management
}

\author{
by E.K. Morgenstern ${ }^{1}$
}

\begin{abstract}
Foresters are among the first professionals that developed principles for sustainability. The need for sustainable forests was first expressed in Germany by H.K. von Carlowitz in 1713. Since about 1800 methods to achieve sustainability based on wood volume, forest area, or growing stock have been introduced in all jurisdictions in Germany and Austria. The general acceptance of the sustainability principle, improved education and professionalism of foresters, and the reform of forest administrations have all contributed to the success of forestry in central Europe. In Canada, forest conservation and sustainable management have been discussed since 1907 when university education in forestry was initiated, and sustainability is now firmly established in all provinces.
\end{abstract}

Key words: history of forestry, forest inventory, forest regulation, forest management, G.L. Hartig, H. Cotta, J.C. Hundeshagen, B.E. Fernow

\section{RÉSUMÉ}

Les forestiers sont parmi les premiers professionnels à avoir développés les principes de la durabilité. La nécessité d'avoir des forêts durables a été exprimée une toute première fois en Allemagne par H.K. von Carlowitz en 1713. Depuis environ 1800, des méthodes pour atteindre la durabilité en terme de volume de matière ligneuse, de superficie forestière ou de stock en croissance ont été mises en place par tous les paliers administratifs d'Allemagne et d'Autriche. L'acceptation générale du principe de durabilité, l'amélioration de la formation académique et le professionnalisme des forestiers, ainsi que la réforme de la gestion forestière ont permis ensemble le succès de la foresterie en Europe centrale. Au Canada, la conservation des forêts et l'aménagement durable ont fait l'objet de discussions depuis 1907 lorsque la formation académique universitaire en foresterie a fait ses débuts, et actuellement la durabilité est maintenant solidement implantée dans toutes les provinces.

Mots clés : histoire de la foresterie, inventaire forestier, régularisation des forêts, aménagement forestier, G.L. Hartig, H. Cotta, J.C. Hundeshagen, B.E. Fernow

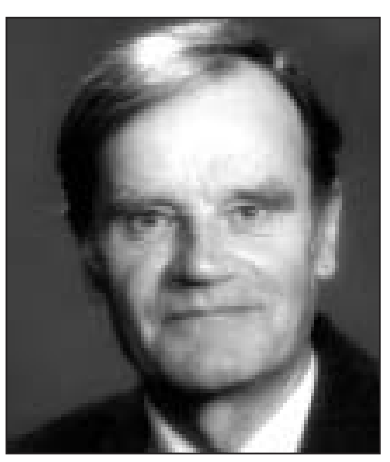

\section{Introduction}

Sustainable forestry is defined as "Management of forested area in order to provide wood products in perpetuity, soil and watershed integrity, persistence of most native species and maintenance of highly sensitive species or suitable conditions for continued evolution of species" (Natural Resources Canada 1995). Sustainability of the resource is the objective of all forest management plans, and is now demanded by society for all living organisms affected by human management, be it agriculture, fisheries, tourism, recreation and other endeavours. In Ontario, for example, public forests are managed according to the Crown Forest Sustainability Act of 1994 (Bell et al. 2006).

It is not generally known that the principle of sustainability is a key idea developed in classical forestry 200 years ago. Foresters therefore have been pioneers and leaders in the quest to avoid the crisis caused by exploitation, a degraded environment, and the resulting collapse of economic activity
- conditions that contributed, for example, to the decline of the Roman Empire and other civilizations (Homer-Dixon 2006). In his review of forest policy, Greeley (1953) pointed out that the original sustainability principles were developed in Europe, primarily in Germany and Austria. The concept of "sustainability" first appeared in 1713. The German word for it is "Nachhaltigkeit," and this became the key principle of the newly developing forestry discipline of "Forsteinrichtung." Literally translated this is "setting up the forest," and in English forestry terminology includes forest inventory, forest regulation, and forest management planning.

The idea of forest conservation came naturally to foresters, and the application of the principle of sustainable management involved the development of methods that would allow perpetual use of the forest. These methods were gradually developed as the profession matured and gained respect in the public domain. This paper reviews these developments and the achievements of the pioneers.

\section{Forest Conditions and Administration in the 17th and 18th Centuries}

The principle of sustained yield (like forestry in general) was "a child of necessity." Three hundred years ago the forests of central Europe were in poor condition. Growing populations,

1323 Sandy Beach Road, R.R. 7, Pembroke, Ontario, K8A 6W8. E-mail: krismo@magma.ca 
the development of industrial processes, and the absence of energy sources other than wood led to excessive harvesting and subsequent wood shortages. Because the means of transportation were very inadequate at that time, such shortages occurred particularly near cities, and where large quantities of wood were used for heating, house construction, smelting of ores, shipbuilding, mining, salt-works, and in charcoal and potash production. Forests were also used in large measure to support agriculture by cattle grazing, driving hogs into oak and beech forests, and by supplying litter for barn animals. As a result of these practices, forest areas often consisted of large clearcuts and poorly stocked stands of low productivity (Gärtner 1991).

Forest administrations at that time were not well organized and inefficient, largely because higher officials were economists with little knowledge of the dynamic nature of the forest or had been appointed from the nobility without regard to professional qualifications.

Improvements in these conditions came gradually over time and at different times in the various regions of the country, since the German-Austrian Empire (which existed until 1806) was decentralized and consisted of many duchies and some kingdoms, over 20 in all. The first measures were simple regulations to carry out forest inspections and volume estimates during the 15th and 16th centuries in Austria and Bavaria. A more advanced attempt to balance supply and demand, consisting of forest ordinances for the division of forests into operating units, was instituted in France in 1669 and in Prussia in 1740 (Mantel 1948).

In 1713 the need for sustainability was expressed for the first time by the Saxonian mining director Hans Karl von Carlowitz. . The many silver mines that generated the wealth of the King of Saxony required large quantities of wood. In his "Sylvicultura oeconomica" von Carlowitz encouraged measures for regeneration and stated that a great scientific effort was required to develop a system for the continuous and sustainable management of forests, without which the country would suffer. The first German forestry dictionary, published by J.F. Stahl in 1773, likewise demanded that forest management be organized in such a way that sustainable and economic yields can be obtained (Gärtner 1991).

The end of the 18th century was marked by a rapid development of sciences including botany and forestry. Schools of forestry were founded in many areas and signalled the beginning of a very creative period. Lively discussions in forestry journals ensued, and numerous books contained descriptions of individual tree species and their development; soils and climate were described more scientifically. Specific forestry disciplines, especially "Waldbau" (silviculture) and "Forsteinrichtung" (as defined above), emerged. The Thuringian forester Karl Christoph Oettelt used the term "Forsteinrichtung" in 1763 for the first time (Schwartz 1959). Artificial regeneration by seeding and planting was organized and in some areas practiced on a substantial scale, as in Thuringia (von Minkwitz 1961). Stem analysis, volume and yield tables were being used. The increment borer was invented by Max Robert Pressler (1815-1886) while teaching at the Forest Academy in Tharandt (1840-1882). The beginning of university-level education of foresters in Austria, Bavaria, Hesse, Prussia and Saxony early in the 19th century meant that forest services were reorganized and professional foresters rose to high positions and replaced economists.
Old privileges, based on class and hunting customs, were gradually abolished, as was the traditional practice of collecting litter in the forest. For example, in Württemberg, the chief forester Johann Georg von Seutter (born 1769), radically reformed the forest service by reclassifying numerous positions, placing trained foresters in control (0tt 1998). The higher level of education allowed foresters to benefit from research results of scientists in related biological disciplines and to correspond with intellectuals of the day. Thus, Heinrich Cotta (1763-1844) frequently referred to the eminent French scientist Henri Louis Du Hamel Du Monceau. He corresponded with and was visited by the famous poet Johann Wolfgang von Goethe (who was also an amateur scientist and at times a minister in the Grand Duchy of SaxeWeimar-Eisenach in Thuringia), and by the great geographer Alexander von Humboldt in Prussia (Richter 1950, Schwartz 1990).

\section{Methods Based on Volume and Area}

The systematic planning for sustained yield based on volume at that early period is credited foremost to Georg Ludwig Hartig (1764-1849). He was first the director of a forestry school in Hesse, then briefly took a position in Württemberg, and in 1811 was appointed head of the forest service in Prussia. His book "Instructions for the inventory and description of forests" appeared in 1795 and received much attention. He suggested a division of the forest into equal areas and age classes of 30 years. The maintenance of an adequate level of growing stock to assure sustainability was recommended, and the probability of an increasing demand for wood and the creation of reserves were anticipated. Most important was Hartig's comment on the sustained-yield principle (cited by Gärtner 1991, page 10):

"Every wise forest administration therefore must survey its forest estate without delay and make plans, but in such a manner that future generations can benefit from the forest just as much as the present generation.'

Hartig clearly expresses the advantages of knowing the resource better and at the same time reminds foresters of their responsibility to future generations (Mantel 1948, Brasnett 1953, Gärtner 1991).

The next stage in the development of methods for sustainable management was the area framework, an approach to spatial control initiated by Heinrich Cotta in Saxony. Cotta was born and received his early training in Thuringia, attended the University of Jena, and directed a forestry school. The Grand Duke at Weimar recognized his abilities and promoted him early. In 1811 he was appointed director of the forest inventory and planning section in neighbouring Saxony. He was allowed to move his forestry school to Tharandt near Dresden, which in 1816 became the Royal Saxonian Forest Academy. This is now the Forestry Faculty of the Technical University of Dresden (Richter 1950).

Cotta's text entitled, "Systematic procedures for inventory of forests," was published in 1804. He stated that it is usually more important to establish spatial order than to estimate volumes. The basic unit considered in this approach is the compartment. An example of a compartment in lowlands is a rectangular block measuring 400 by 800 meters ( 32 hectares), which usually consisted of several subcompartments distinguished on the basis of species composition, age class, and site. In mountains, compartments are irregular in shape and 
adapted to the local conditions of forest type, elevation, exposure, drainage and transportation possibilities (Mantel 1948).

In his more comprehensive text of 1832, entitled "Basic principles of forest science," Cotta wrote (cited by Richter 1950, page 160):

"The sustainability of natural yield is assured, when in each successive evaluation of utilization and management, stands are recognized that reflect the natural productivity of the site and have an approximately equal proportion of age classes. A completely equal yield from year to year is not absolutely necessary, neither from a broad economic point of view, nor from a technical forestry perspective, because the ideal stand conditions may not as yet have been obtained, and also because an increase in yield is within the range of possibilities."

The information required for a 10-year management plan was listed as follows:

a) a general description of the forest and of the inventory methods used;

b) a list of all stands by age classes;

c) an outline of the expected general harvesting schedule;

d) a list of past annual harvest volumes;

e) a specific harvest schedule for the next 10 years with information on expected volumes;

f) a regeneration plan for the next 10 years.

The types of maps and their scales, as well as the inventory schedule and a schedule for future revisions of the management plan were also prescribed by Cotta in this 1832 publication (Richter 1950).

One great advantage of the area framework was the possibility of keeping long-term records of each compartment and sub-compartment and making comparisons from one rotation to the next (Blanckmeister 1956). In most German and Austrian jurisdictions the area framework established about 200 years ago is still in existence.

Combinations of the area framework with volume regulations have been used in various jurisdictions in Germany throughout the 19th and even the 20th century (Mantel 1948).

\section{Methods Based on Growing Stock, Increment, and Age Classes}

As early as 1788, an Austrian forest ordinance used the term "growing stock" and prescribed the determination of volume to be cut on this basis. Discussions of growing stock were then linked to the concept of "the normal forest," which is a fully regulated forest with basic data obtained from yield tables. A schematic presentation of aspects of the normal forest is given in Fig. 1.
Johann Christian Paulsen (1748-1825), forest administrator in the County of Lippe-Detmold in northwestern Germany, suggested in 1787 a method to determine yield that was subsequently improved by Johann Christian Hundeshagen (1783-1834), who was a professor at the Giessen forestry school in Hesse from 1824 to 1831 . In 1826 he published "Forest estimates" (Richter 1950). Davis (1954), in his textbook entitled "American forest management" gives the Hundeshagen equation (Fig. 2). Normal yield tables are used in this equation, keeping in mind the limitations as explained by Davis (1954).

$$
\begin{aligned}
& \frac{Y a}{G a}=\frac{Y r}{G r} \\
& Y a=\frac{Y r}{G r} G a
\end{aligned}
$$

where $\mathrm{Ya}=$ growth or yield in an actual forest $\mathrm{Ga}=$ growing stock in an actual forest

$\mathrm{Yr}=$ growth or yield in a fully stocked forest

$\mathrm{Gr}=$ growing stock in a fully stocked forest

Fig. 2. The Hundeshagen formula developed to determine yield from growing stock (from Davis 1954).

In 1920 the Swiss forester Biolley suggested the "control method," based on ideas of Gurnaud in France and Eberbach in Germany. This method was designed for application in selection forests (Mantel 1948, Brasnett 1953, Davis 1954).

\section{Problems with Pure Stands}

The systematic, large-scale reforestation programs of the 19th and 20th centuries mostly with conifers in central Europe often led to uniform stands of a single species. This system produced high volumes of useful products and was justified for economic reasons by Max Robert Pressler and Friedrich Judeich, both professors at Tharandt in the 1860-1871 period, but was soon challenged by a number of silvicultural writers, for example, Heinrich Christian Burckhart (1811-1879) in his text "Seeding and planting in forestry," which appeared in six editions between 1855 and 1893 .

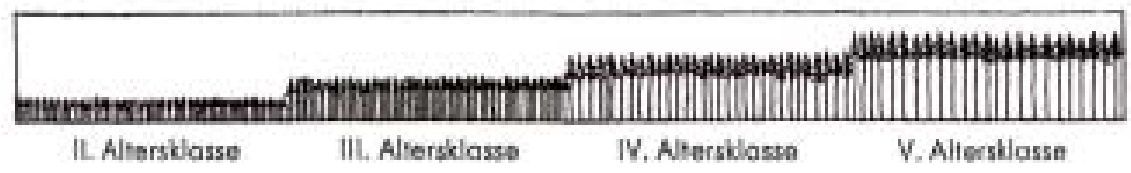

Fig. 1. A "normal forest" with four age classes, II to V. These uniform plantations would be oriented towards the direction of prevailing winds to minimize wind damage. The figure assumes a rotation of about 100 years (from Heger 1950). 
Although pure stands may have performed well in the first rotation, the following harvests from the same area were often lower. A thorough investigation of stands in the lower and middle elevations in the Ore Mountains of Saxony documented excessive raw humus accumulations and growth retardation, as shown in 1923 by Wiedemann (1951). This problem was augmented in the 19th century by the lack of recognition of provenance variation, so that many poorly adapted stands were established (Morgenstern 1996).

Pure stands and the associated rigidity of "normal forest" planning have also been questioned because of excessive wind damage, particularly in mountain forests, neglect of site differences, and low priority given to aesthetics and the recreational and ecological functions of the forest. The requirements of sustainability, at least as recognized today, were not fulfilled.

Many foresters since then have expressed the need for a more natural forest, made up of smaller stands of welladapted, mostly native species that are frequently thinned to improve stem quality and crown form and to increase resistance to extreme atmospheric influences and insects and diseases (Heger 1950, Krutzsch 1952, Blanckmeister 1956, Röhrig and Gussone 1982). During the last two decades a strong trend towards a more mixed forest is evidenced by a substantial increase in the planting of deciduous species, the protection of shrubs, and the high priority given to gene conservation and biodiversity (Kleinschmit 1993).

\section{Sustainable Management in Canada}

European forestry principles have influenced forest management practices in Canada, but could only be introduced gradually as the country moved from exploitation to planned utilization and management-but this development can only be discussed very briefly here.

The first professional forester in North America was German-born Bernhard Eduard Fernow (1851-1923), a graduate of the University of Königsberg and of the Prussian Forest Academy at Hannoversch Münden $\mathrm{He}$ arrived in the United States in 1876 and 10 years later became the first Chief of the Division of Forestry of the U.S. Department of Agriculture. In 1907 he was appointed Dean of the newly established Faculty of Forestry at the University of Toronto. There is no doubt that he taught the principles of sustainable management (which were then well established in Europe) to his students but their application in Canada with its totally different conditions took time. Under Fernow's leadership the Federal Commis-sion of Conservation sponsored and published reports on the forests of Nova Scotia, Ontario, Saskatchewan, and British Columbia (Fensom 1972, Sisam 1982, Johnson 1986, Armson 2001). Although Fernow received only very limited support by his University and the Ontario Government, he received high praise from his colleagues and students. Elected as the first President of the Canadian Society of Forest Engineers in 1908, he remained in this office until 1915. The history of this Society and its successor, the Canadian Institute of Forestry/ Institut Forestier du Canada also records that the subject of sustainable management or sustained yield was discussed many times (Fensom 1972, Sisam 1982).

Today, the principle of sustainability is firmly established in all provinces. The annual report of the Federal Minister of
Natural Resources (Natural Resources Canada 2006), listing the data of individual provinces and the country as a whole, shows that the wood supply based on the annual allowable cut in Canada has exceeded harvest levels for many years. While these data refer only to the trees, it is well known that great efforts are being made to sustain whole ecosystems (The Forestry Chronicle 2006).

\section{Conclusions}

The principle of sustainable management was incorporated in the forest management directives of all Austrian and German states early in the 19th century, although it was interpreted too narrowly at times, as in the Pressler-Judeich prescriptions later in that century. There was a great deal of scientific discussion, and concepts and regulations were gradually improved and adapted to the variable forest conditions in different jurisdictions. During the late 19th century the forestry discipline "Forsteinrichtung" (forest regulation) became the dominant discipline in forestry, and some of its textbooks appeared in many editions. The education of foresters, the organization of forest administrations, and forest productivity all were greatly improved throughout the 19th and 20th centuries, and forest services delivered substantial surpluses to the state. In Canada, too, as the country moved from exploitation to management during the past century, the principle of sustainability was firmly established. As foresters, we can be proud that our profession led the way in the development of principles and practical solutions for renewable resource management that are recognized as being absolutely essential today.

\section{Acknowledgements}

Comments on this paper by Steve D'Eon and Peter Arbour of the Petawawa Research Forest, and by Brian Haddon, Research Editor, are gratefully acknowledged.

\section{References}

Armson, K.A. 2001. Ontario forests: a historical perspective. Fitzhenry \& Whiteside, Markham, ON. 233 p.

Bell, F.W., D.G. Pitt, and M.C. Webster. 2006. Is intensive forest management a misnomer? An Ontario-based discussion of terminology, and an alternative approach. For. Chron. 82 (5): 622-674.

Blanckmeister, J. 1956. Die räumliche und zeitliche Ordnung im Walde (Order in space and time in the forest). Neumann Verlag, Radebeul. 145 p.

Brasnett, N.V. 1953. Planned management of forests. George Allen \& Unwin Ltd., London. 238 p.

Davis, K.P. 1954. American forest management. McGraw-Hill, New York. $482 \mathrm{p}$.

Fensom, K.G. 1972. Expanding forestry horizons. A history of the Canadian Institute of Forestry -Institut Forestier du Canada, 1908-1969. Canadian Institute of Forestry - Institut Forestier du Canada, Macdonald College, Montreal. Printed by Evergreen Press, Vancouver, BC. 547 p.

Gärtner, E.J. 1991. Die Entwicklung des Prinzips der Nachhaltigkeit (Development of the principle of sustainability). Hessian Forest Experiment Station, Hannoversch Münden. 15 p. (unpublished). Greeley, W.B. 1953. Forest policy. McGraw-Hill, New York. 278 p. Heger, A. 1950. Lehrbuch der forstlichen Vorratspflege (Textbook for care of the growing stock). Neumann Verlag, Radebeul und Berlin. 152 p.

Homer-Dixon, T. 2006. The upside of down. Catastrophe, creativity, and the renewal of civilization. Knopf Canada, Toronto. 429 p. 
Johnson, R.S. 1986. Forests of Nova Scotia. A history. Nova Scotia Department of Lands and Forests, Halifax. 407 p.

Kleinschmit, J. 1993. Niedersächsische Forstliche Versuchsanstalt, Abteilung Forstpflanzenzüchtung. Tätigkeitsbericht 1993. (Lower Saxony Forest Research Institute, Forest Tree Breeding Section. Annual report for 1993). Staufenberg-Escherode. 68 p.

Krutzsch, H. 1952. Waldaufbau (Forest structure). Deutscher Bauernverlag, Berlin. 159 p.

Mantel, W. 1948. Forsteinrichtungslehre (Forest regulation), Neumann Verlag, Radebeul und Berlin. 229 p.

Morgenstern, E.K. 1996. Geographic variation in forest trees. UBC Press, Vancouver. 209 p.

Natural Resources Canada. 1995. Silvicultural terms in Canada. 2nd ed. Ottawa. 109 p. Available from http://nfdp.ccfm.org/silviterm/ silvi_e/silvitermintroe.htm

Natural Resources Canada. 2006. The state of Canada's forests 2005-2006. Ottawa. 79 p. Available from http://cfs.nrcan.gc.ca/sof/ latest_e.html

Ott, W. 1998. Die grüne Wende. Wie die Forstwirtschaft in Württemberg reformiert wurde (Turning green. How forestry in Württemberg was reformed). Stuttgarter Zeitung 31. Januar 1998. 1 p. Richter, A. 1950. Heinrich Cotta. Neumann Verlag, Radebeul und Berlin. 247 p.

Röhrig, E., and H.A. Gussone. 1982. Waldbau auf ökologischer Grundlage, begründet von Alfred Dengler, 5. Auflage. Bd. II.
Baumartenwahl, Bestandesbegründung und Bestandespflege. (Silviculture on an ecological basis, by Alfred Dengler, 5th ed. Vol. II. Choice of species, stand establishment and care). Verlag Paul Parey, Hamburg und Berlin. 280 p.

Schwartz, E. 1959. Die Forsteinrichtung von 1763 und 1765 in Sachsen-Weimar-Eisenach (Forest inventory and regulation in 1763 and 1765 in Sachsen-Weimar-Eisenach). Archiv für Forstwesen 8: 337-360.

Schwartz, E. 1990. 120 Jahre forstliches Versuchswesen in Eberswalde (120 years of forest research at Eberswalde). Institute of Forest Sciences, Eberswalde. 65 p.

Sisam, J.W.B. 1982. Forestry and forestry education in a developing country. A Canadian dilemma. Faculty of Forestry, University of Toronto. Printed by University of Toronto Press. $167 \mathrm{p}$

The Forestry Chronicle. 2006. Volume 82, No.3. May /June. Special issue on biodiversity management.

von Minkwitz, H. 1961. Einführung der künstlichen Bestandesbegründung im Thüringischen Schiefergebirge (Introduction of artificial regeneration in the Thuringian Slate Mountains). Archiv für Forstwesen 10:94-108.

Wiedemann, E. 1951. Ertragskundliche und waldbauliche Grundlagen der Forstwirtschaft (Growth-and-yield science and silvicultural basis of forestry). J.D. Sauerländers Verlag, Frankfurt. 346 p. 